\title{
Cytogenetic disorders in Triticum aestivum $L$. cells affected by radionuclide contamination of water reservoirs in the alienation zone of Chornobyl NPP
}

\author{
R. A. Yakymchuk \\ Institute of Plant Physiology and Genetics, NAS of Ukraine \\ 31/17, Vasylkivska, Kyiv, Ukraine, 03022 \\ peoplenature16@gmail.com
}

\begin{abstract}
Aim. To study frequency and spectrum of chromosome aberrations in the cells of Triticum aestivum $L$. root meristem under a prolonged effect of radionuclides from water reservoirs in the proximal alienation zone of the Chernobyl nuclear power plant NPP. Methods. The seeds of two soft winter wheat varieties were treated with samples from water reservoirs in the alienation zone of the Chernobyl NPP. Ana-telophase analysis of chromosome aberrations in crushed cytological preparations of apical meristem of primary rootlets was carried out. Results. Radionuclides from water reservoirs in the proximal alienation zone of the Chornobyl NPP cause an increase in the occurrence of aberrant cells and mitoses by 1.6-4.2 times. The highest level of cytogenetic activity is typical for the radionuclides from the reservoir-cooler of the Chernobyl NPP, Semyhodskyi backwater, drainage N 3 of the NPP and Lake Hlyboke. The obseved aberrations are mostly represented by single and paired acentric fragments, bridges and lagging chromosomes. Conclusion. A prolonged exposure to ionizing radiation by radionuclides from the water reservoirs of the proximal alienation zone of the Chernobyl NPP produces leads to high cytogenetic activity. No correlation between the chromosome aberration level and the scope of specific radionuclides from water reservoirs was found; this may prove the induction of cytogenetic disorders under the radiation effect in the low-rate range. The increased level of aneuploid cells and those with multiple chromosome aberrations confirms genetic consequences for the organisms in water reservoirs even with a low specific activity of radionuclides.
\end{abstract}

Ke y w or d s: Aberrations, cytogenetic disorders, radionuclide, low-rate radiation.

\section{Introduction}

The genetic changes in the organism are among the most dangerous consequences of radionuclide contamination of the environment re- sulted from the accident at Chornobyl NPP. They appear in various forms of pathologies, development and growth delay, intelligence decrease, shorter life expectancy and death of an individual [1]. All the time, beginning from

(C) 2018 R. A. Yakymchuk; Published by the Institute of Molecular Biology and Genetics, NAS of Ukraine on behalf of Biopolymers and Cell. This is an Open Access article distributed under the terms of the Creative Commons Attribution License (http://creativecommons.org/licenses/by/4.0/), which permits unrestricted reuse, distribution, and reproduction in any medium, provided the original work is properly cited 
the accident till present day, mutagenic activity of low-rate prolonged and chronic radiations and their genetic after-effects in combination with chemical anthropogenic factors of the environment have been the most crucial issue for discussion. Numerous researches of radionuclide contaminations in the alienation zone of ChNPP with the use of plant test-objects enabled the solution of the issue. Most of them are carried out in the dry land or in laboratories using soil samples [2-4]. However, insufficient attention is paid to studying the genetic consequences of radionuclide contaminations of superficial waters of Chornobyl alienation zone, the radio-ecological situation in which is determined by the quantity of radioactive substances on the water surface and a complicated complex of continuous interactions of adjacent environments [5]. Several hydro-biological studies of the alienation zone of Chornobyl NNP [6-8] identified a high level of chromosome aberrations in embryonic tissues of fish, shellfish and root meristem of higher water plants, uncharacteristic pathological branching of reed, abnormal formations near racemes, fluctuating asymmetries of shellfish shucks, abnormalities in reproductive systems and fish organs, cancer genesis of animals, reduced resistance to pests and diseases, increased mortality. Mutations in hydro bionites are mostly induced by chronic effect of incorporated $\alpha$ - and $\beta$-radiated radio nuclides, which, when located in cell nucleus and DNAprotein complexes, cause a relatively high biological effect of internal radiation. The role of the external $\gamma$-radiation share in the formation of total mutagenicity of water reservoirs at later dates after the accident at ChNPP requires further studying.
It is a known fact that the most informative and sensitive markers of mutagen contamination, in particular a chronic low-rate radiation impact, are cytogenetic indicators, namely chromosome aberrations in plant cells $[9,10]$. The calculations, based on the studies of radiation after-effects, showed that the probability to identify chromosome aberrations is $10^{3}-10^{4}$ times higher than that of the identification of individual locus mutation [11], and the evaluation of a mutative process with the help of cytogenetic analysis gives the results which match those, received by the method of electrophoretic analysis of isoenzymes $[12,13]$.

The purpose of the work was to study the frequency and spectrum of chromosome aberrations in the root meristem cells of Triticum aestivum $L$. affected by prolonged radionuclide contamination of water reservoirs in the near alienation zone of Chornobyl NPP.

\section{Materials and Methods}

Seeds of two soft winter wheat varieties (T. aestivum L.) Al'batros odes'kyi and Zymoiarka were treated with water samples from the Prypiat River (Chornobyl city), the Brahinka River (dike N 39), a reservoir-cooler of ChNPP (a coastal pump station), Semyhodskyi backwater, drainage-way N 3 of ChNPP, Lakes Hlyboke and Azbuchyn. Specific activity of ${ }^{137} \mathrm{Cs}$ and ${ }^{90} \mathrm{Sr}$ was $0.17 \mathrm{kBq} / \mathrm{m}^{3}$, $2.53 \mathrm{kBq} / \mathrm{m}^{3}, 2.1 \mathrm{kBq} / \mathrm{m}^{3}, 7.76 \mathrm{kBq} / \mathrm{m}^{3}$, $91.99 \mathrm{kBq} / \mathrm{m}^{3}, 70.08 \mathrm{kBq} / \mathrm{m}^{3}, 52.99 \mathrm{kBq} / \mathrm{m}^{3}$, respectively. Water samples from tentatively clean Holosiivske Lake in Kyiv were taken as the control, specific activity of ${ }^{137} \mathrm{Cs}$ and ${ }^{90} \mathrm{Sr}$ in it was $0.02 \mathrm{kBq} / \mathrm{M}^{3}$. Water samples were taken in 2015 according to the standard techniques $[14,15]$. Specific activity of ${ }^{137} \mathrm{Cs}$ and 
${ }^{90} \mathrm{Sr}$ in water was measured in state-run specialized company "Chornobyl specialized complex" using $\gamma$-spectrometric complex and low-background $\beta$-radiometer.

50 seeds per variant of the trial were kept in the above-mentioned samples for $18 \mathrm{~h}$, then they were sown in Petri dishes on filtered paper, wetted with the water of the mentioned samples at temperature $24-26{ }^{\circ} \mathrm{C}$. Primary rootlets, $0.8-1.0 \mathrm{~cm}$ long, were fixed during $4 \mathrm{~h}$ in Clark device which contained $96 \%$ solution of ethanol and acetic acid in proportion $3: 1$. Chemical maceration of rootlets was done during $1 \mathrm{~min}$ in $1 \mathrm{~N}$ solution of hydrochloric acid. After maceration, the rootlets were placed in aceto-orcein solution for $24 \mathrm{~h}$ at $23-25{ }^{\circ} \mathrm{C}$ to analyze chromosome aberrations and disorders of cell mitosis.

For microscopic analysis, the temporary crushed cytological preparations were made in accordance with generally accepted techniques [16]. Meristemic zone of rootlets was studied with the use of microscope "JENAVAL" (Carl Zeiss Jena) at magnification $900 \mathrm{x}$. When determining frequency of chromosome aberrations and mitosis disorders, the cells at an anaphase and an early telophase were taken into consideration. Sampling for each variant was at least 1000 cells which were studied in 20 and more primary rootlets. Frequency of aberrant cells was considered as the percentage of cells at an anaphase and an early telophase which had chromosome disorders. When average number of aberrations per an aberrant cell (NAperAC) was calculated, the cells from 0 , 1,2 and those with multiple chromosome aberrations ("> $>2$ " aberrations) were taken into account. Statistic processing of experimental data was carried out according to generally accepted techniques [17], the variation validity was estimated by Student's $t$-criterion. Percent shares of chromosome aberrations and errors are given in the tables.

\section{Results and Discussions}

An increase in frequency of chromosome aberrations and mitosis disorders by 1.6-4.2 times was recorded in meristemic cells of primary rootlets of wheat affected by radiation in water reservoirs and watercourses in the alienation zone of ChNPP. The highest level of cytogenetic activity is typical for water samples taken from a reservoir-cooler of ChNPP and Semyhodskyi backwater. The frequency of chromosome aberrations exceeds the control by $2.8-4.2$ times and it is $1.77 \pm 0.32 \%$ and $1.90 \pm 0.36 \%$ in rootlet meristemic cells of variety Al'batros odes'kyi and $2.21 \pm 0.40 \%$ and $2.28 \pm 0.43 \%$ in variety Zymoiarka (Table 1). The contamination effect with the highest specific activity of ${ }^{137} \mathrm{Cs}$ and ${ }^{90} \mathrm{Sr}$ in drainage-way N 3, Lake Hlyboke and Lake Azbuchyn on root meristem of wheat rootlets did not lead to a rapid increase in aberrant cell frequency. Under the effect of radionuclide contamination of water in drainage-way N 3 and Lake Hlyboke, the frequency of cells with chromosome aberrations of variety Zymoiarka was $1.96 \pm 0.41 \%$ and $1.53 \pm 0.38 \%$, which exceeds considerably a spontaneous level by 2.8 and 3.6 times, respectively. Statistically reliable frequency increase of cells with chromosome aberrations of variety $\mathrm{Al}$ 'batros odes'kyi, under the effect of radionuclide contamination of the mentioned water reservoirs, was not observed, however, their level exceeded the control by 1.9 and 2.0 times. An increase in the aberrant cell frequency of varieties Al'batros odes'kyi and 
Zymoiarka by 1.6 and 2.2 times was recorded in the conditions of the effect of radionuclide water contamination of Lake Azbuchyn, when the statistically reliable variation with spontaneous indicators was not observed.

Other researchers recorded a complicated non-linear dependence of dose-effect in a lowrate area under chronic radiation in the alienation zones of ChNPP and Easter-Ural radiation areas; and it concerned covering crepis (Crepis tectorum L.) [18], barley (Hordeum vulgare L.) of waxy line, brown frogs (Rana temporaria L.), red voles (Clethrionomys glareolus L.) [19], Chinese hamster (Cricetulus griseus L.), human cells [20]. The lack of correlation between the genetic disorders and radiation doses is associated, under some conditions of cell damage, with the onset of functioning of inducible reparation and cyto-protector processes which increase the radio-resistance of cell population [1].
The correlation between the frequency of chromosome disorders and the scope of specific activity of ${ }^{137} \mathrm{Cs}$ contamination of water and soil was found out in other studies. This concerned reed (Phragmites australis L.), lymnaea (Lymnaea stagnalis L.) [6], pine (Pinus sylvestris L.) $[13,21]$, thin bluegrass (Koeleria gracilis L.) [22], biennial goat's-rue (Oenothe rabiennis $L$.), and they all were affected by chronic high-dose external and internal ionizing radiation. Accordingly, the real dose load on meristem cells can exceed by an order the doses calculated for steady irradiation of plant cells $[6,19]$.

The levels of cytogenetic disorders under the effect of radio nuclides in water of the Prypiat River (Chornobyl city) are $1.06 \pm 0.29 \%$ for meristem cells of variety Al'batros odes'kyi and for variety Zymoiarka $1.18 \pm 0.33 \%$, exceeding the indicators of spontaneous chromosome disorders by 1.7 and 2.2 times, respectively. An increase in the

Table 1. The frequency of chromosome aberrations in winter wheat under the effect of radionuclide contamination of water reservoirs in the alienation zone of ChNPP

\begin{tabular}{|c|c|c|c|c|c|c|}
\hline \multirow[t]{3}{*}{ Place where samples were taken } & \multirow[t]{2}{*}{$\begin{array}{c}\text { Studied } \\
\text { ana-telophases } \\
\text { of mitosis, pcs }\end{array}$} & \multicolumn{2}{|c|}{$\begin{array}{l}\text { Mitosis with } \\
\text { velydisorders } \\
\text { and chromosome } \\
\text { aberrations }\end{array}$} & \multirow[t]{2}{*}{$\begin{array}{l}\text { Studied } \\
\text { ana-telophases } \\
\text { of mitosis, pcs }\end{array}$} & \multicolumn{2}{|c|}{$\begin{array}{l}\text { Mitosis with disorders } \\
\text { and chromosome } \\
\text { aberrations }\end{array}$} \\
\hline & & pcs & $\%$ & & pcs & $\%$ \\
\hline & \multicolumn{3}{|c|}{ Al'batros odes'kyi } & \multicolumn{3}{|c|}{ Zymoiarka } \\
\hline Lake Holosiivske (the control) & 1277 & 8 & $0.63 \pm 0.22$ & 1088 & 6 & $0.55 \pm 0.22$ \\
\hline the Prypiat River, Chornobyl city & 1230 & 13 & $1.06 \pm 0.29$ & 1103 & 13 & $1.18 \pm 0.33$ \\
\hline the Brahinka River, dike N 39 & 1067 & 13 & $1.22 \pm 0.34$ & 1317 & 15 & $1.14 \pm 0.29$ \\
\hline a reservoir-cooler of ChNPP & 1693 & 30 & $1.77 \pm 0.32 *$ & 1358 & 30 & $2.21 \pm 0.40^{*}$ \\
\hline Semyhodskyi backwater & 1473 & 28 & $1.90 \pm 0.36^{*}$ & 1187 & 27 & $2.28 \pm 0.43 *$ \\
\hline drainage-way N 3 ChNPP & 1490 & 19 & $1.28 \pm 0.29$ & 1173 & 23 & $1.96 \pm 0.41^{*}$ \\
\hline Lake Hlyboke & 1424 & 17 & $1.19 \pm 0.29$ & 1049 & 16 & $1.53 \pm 0.38^{*}$ \\
\hline Lake Azbuchyn & 1599 & 16 & $1.00 \pm 0.25$ & 1070 & 13 & $1.22 \pm 0.34$ \\
\hline
\end{tabular}

Note: * variation with the control is statistically reliable at $\mathrm{P}<0.05$ 
frequency of aberrant cells by 1.9 and 2.1 times $(1.22 \pm 0.34 \%$ in variety Al'batros odes'kyi and $1.14 \pm 0.29 \%$ in variety Zymoiarka) was also found in meristem of primary rootlets which were affected by radionuclide contamination of water in the Brahinka River. The lack of statistically reliable variation between the aberrant cell frequency of wheat root meristem, affected by prolonged ionizing radiation of radionuclide contamination of water reservoirs in the alienation zone of ChNPP (Lake Azbuchyh, the Prypiat River and the Brahinka River), and the control confirm the fact that the indicators of cytogenetic activity of some watercourses and water reservoirs of the alienation zone of ChNPP are closer to a spontaneous level. However, an increase in chromosome aberration frequency by two times compared with the level of spontaneous cytogenetic disorders proves the after-effects of double-dose irradiation of meristem cells and mutagenic danger of existing low-rate radionuclide contamination of the mentioned water reservoirs and watercourses in the near alienation zone of ChNPP.

The control of the correlation of chromosome disorders of various types is very important when radio ecological studies are carried out. Under a relatively low stress effect, the change of mitosis disorder spectrum occurs, only after which the pathology cases increases [9]. A spectrum of the chromosome aberration types and mitosis disorders in the conditions of radionuclide contamination of water reservoirs in the alienation zone of ChNPP is mostly presented by acentric fragments, bridges and lagging chromosomes (Fig. 1A-D). There is an opinion that the increased level of acentric fragments is the indicator of prolonged low-rate radiation. It has been shown that the radiationinduced in $\mathrm{G}_{2}$-period chromatide breaks develop at the moment of chromatin condensation and chromatine fiber formation [23]. Bridges appear as the result of both breach and consolidation of broken chromosome ends and agglutination (chromosome conglutination) [24]. The level of acentric fragments and bridges in meristemic cells of variety Al'batros odes'kyi, caused by radionuclide contamination of water reservoirs in the alienation zone of ChNPP, exceeds the control by $1.4-4.4$ and 1.2-2.5 times, respectively (Table 2 ). The largest number of acentric fragments which exceeded their spontaneous induction by 2.9 and 4.4 times was recorded in the conditions of radioactive contamination of a reservoir-cooler of ChNPP and Semyhodskyi backwater (Fig. 2). The number of acentric fragments and bridges in meristemic cells of variety Zymoiarka, induced by radiation of radionu-

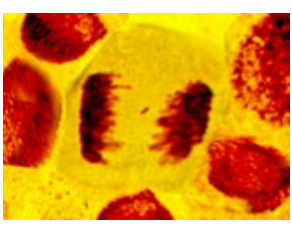

A

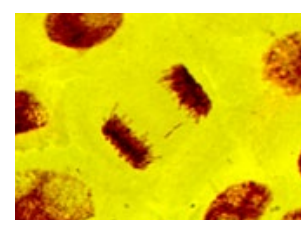

$B$

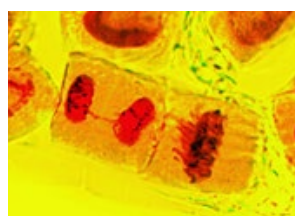

$C$

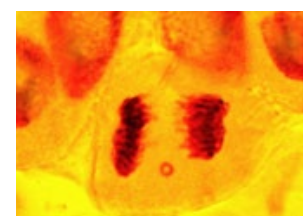

$D$

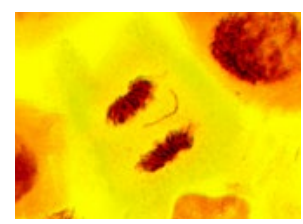

$E$

Fig. 1. Types of aberrations and mitosis disorders, induced by radionuclide contamination of water reservoirs of the near alienation zone of ChNNP: $A$ - singular acentric fragment, $B$ - double acentric fragments, $C$ - bridge, $D$ - ring chromosome, $E$ - lagging chromosome. 
Table 2. Spectrum of chromosome aberration types in winter wheat under the effect of radionuclide contamination of water reservoirs in the alienation zone of ChNPP

\begin{tabular}{|l|l|l|l|l|l|l|l|l|l|}
\hline \multirow{2}{*}{ Sampling places } & \multicolumn{6}{|c|}{ Spectrum of mitosis disorders and chromosome aberrations, \% } & \multirow{2}{*}{ NAperAC } \\
\cline { 2 - 5 } & F & B & B+F & MC & LCh & RCh & \\
\hline Al'batros odes 'kyi & 50.0 & 37.5 & 0.00 & 0.0 & 12.5 & 0.0 & 1.00 \\
Lake Holosiivske (the control) & 53.8 & 23.1 & 0.00 & 0.0 & 23.1 & 0.0 & 1.23 \\
the Prypiat River, Chornobyl city & 53.8 & 23.1 & 7.7 & 0.0 & 15.4 & 0.0 & 1.15 \\
the Brahinka River, dike N 39 & 50.0 & 30.0 & 0.0 & 3.3 & 13.4 & 3.3 & $1.20^{*}$ \\
a reservoir-cooler of ChNPP & $71.4^{*}$ & 14.3 & 3.6 & 3.6 & 7.1 & 0.0 & $1.32^{*}$ \\
Semyhodskyi backwater & 42.1 & 47.3 & 5.3 & 5.3 & 0.0 & 0.0 & $1.21^{*}$ \\
drainage-way N 3 ChNPP & 35.3 & 23.5 & 0.0 & 11.8 & 29.4 & 0.0 & 1.12 \\
Lake Hlyboke & 50.0 & 31.2 & 0.0 & 0.0 & 18.8 & 0.0 & 1.19 \\
Lake Azbuchyn & 83.3 & 16.7 & 0.0 & 0.0 & 0.0 & 0.0 & 1.17 \\
Zymoiarka & 53.8 & 38.5 & 0.0 & 0.0 & 7.7 & 0.0 & 1.31 \\
Lake Holosiivske (the control) & 60.0 & 13.3 & 0.0 & 0.0 & $26.7 *$ & 0.0 & 1.13 \\
the Prypiat River, Chornobyl city & 43.3 & $46.7^{*}$ & 0.0 & 3.3 & 6.7 & 0.0 & 1.13 \\
the Brahinka River, dike N 39 & 33.3 & $66.7^{*}$ & 0.0 & 0.0 & 0.0 & 0.0 & 1.11 \\
a reservoir-cooler of ChNPP & 43.5 & $34.8^{*}$ & 4.3 & 0.0 & 13.1 & 4.3 & 1.09 \\
Semyhodskyi backwater & 62.5 & 12.5 & 0.0 & 0.0 & $25.0^{*}$ & 0.0 & 1.31 \\
drainage-way N 3 ChNPP & 38.5 & $53.8^{*}$ & 0.0 & 0.0 & 7.7 & 0.0 & 1.15 \\
Lake Hlyboke & & & & & & \\
Lake Azbuchyn
\end{tabular}

Note: $F$ - acentric fragments, $B$ - bridges, $\mathrm{F}+\mathrm{B}$ - acentric fragments and bridges, $\mathrm{MC}$ - micronuclei, $\mathrm{LCh}-$ lagging chromosomes, $\mathrm{RCh}$ - ring chromosomes;

* variation with the control is statistically reliable at $\mathrm{P}<0.05$

clide contamination of water reservoirs in the alienation zone of ChNPP, increases by 1.4-2.1 and 1.7-16.9 times, respectively. Based on the level of bridge induction, including double ones, in the cells of variety Zymoiarka, the highest mutagenic activity was characteristic of radioactive contamination of a reservoircooler of ChNPP, drainage-way N 3 of ChNNP, Lake Azbuchyn and Semyhodskyi backwater.

The connection between the areas with radioactive contamination and the formation of double and multiple dicentrics is underlined in the works of other researchers [25].
Spectrum of chromosome aberration types in root meristem of wheat under the effect of radionuclide contamination of a reservoir-cooler of ChNPP and drainage-way N 3 of ChNPP extends due to the induction of ring chromosomes, which, together with paired fragments and bridges, are markers of a radioactive effect (Fig. 1E) [25, 26]. The formation of ring chromosomes is considered to be connected with the place exchange of two arms of the same chromosome with conglutination of its proximal ends [26].

Single micronuclei, which develop mostly from acentric fragments and are sensitive 


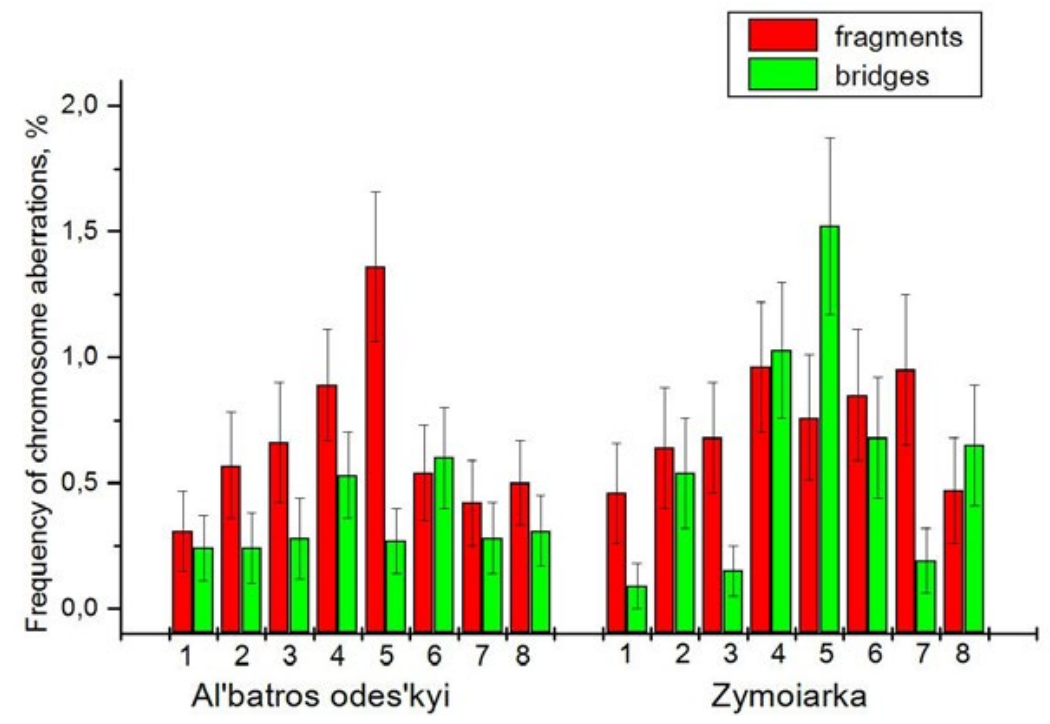

Fig. 2. Induction of acentric fragments and bridges with radionuclide contamination of water reservoirs in the near alienation zone of ChNPP: 1 - Lake Holosiivske (the control); 2 - the Prypiat River, Chornobyl city; 3 - the Brahinka River, dike $\mathrm{N} 39 ; 4$ - a reservoir-cooler of ChNPP; 5 - Semyhodskyi backwater; 6 - drainage-way N 3 of ChNPP; 7 - Lake Hlyboke; 8 - Lake Azbuchyn. markers of the environment mutagenicity, occur in spectrum of cytogenetic disorders, induced by radioactive contamination of a reservoir-cooler of ChNPP, drainage-way N 3 of ChNPP and Semyhodskyi backwater [27].

The chromosome non-disjunction is of special interest, as the process consists of initial damages of spindle protein of cell division rather than DNA. The highest share of aneuploid cells $-29.4 \%$ - was recorded in variety Al'batros odes'kyi under the effect of radionuclide contamination of water in Lake Hlyboke, and $25.0 \%$ and $26.7 \%$ - in variety Zymoiarka under the effect of radionuclide contamination of water in Lake Hlyboke and the Brahinka River, respectively. A considerable share of cytogenetic disorders $-23.1 \%-$ belongs to lagging chromosomes in meristem cells of variety Al'batros odes'kyi which were affected by water mutagens of the Prypiat River. According to the data of some authors [28], the revealed type of chromosome apparatus disorder occurs rarely in the popula- tions, not affected by mutagen factors, which confirms that the disorders of cell division processes resulted from chromosome nondisjunction when the spindle division is blocked. Minor frequency of cells with lagging chromosomes, induced by the contamination of other water reservoirs in the alienation zone of ChNPP, allows assuming a low content of aneugenes in them - substances, which influence the cell division apparatus, and increase a content of clastogenes - substances, which affect chromosomes directly.

The indicator NAperAC is not in direct correlation with the aberrant cell frequency and it is a different quantitative feature of cytogenetic activity of radioactive environmental contamination [29]. It has been established that NAperAC is the highest for variety Al'batros odes'kyi under the effect of water contamination of Semyhodskyi backwater (1.32), the Prypiat River (1.23), reservoircooler of ChNPP (1.20) and drainage-way N 3 of ChNPP (1.21), and for variety Zymoiarka - 
under the effect of water contamination of the Prypiat River and Lake Hlyboke (1.31). Hence, natural water reservoirs of the alienation zone of ChNNP, the radionuclide contamination level of which is characterized by high cytogenetic activity, induce, with high frequency, the cells with complex chromosome reconstructions, which is considered to be a specific biological effect of ionizing radiation. Despite low frequency of the cells with chromosome aberrations, the activity of radionuclides in water of the Prypiat River causes an increase of the cells with multiple aberrations in meristem of wheat rootlets.

\section{Conclusions}

A prolonged effect of ionizing radiation of radionuclide contamination of water reservoirs of the near alienation zone of ChNPP is characterized by a high cytogenetic activity, which exceeds a spontaneous level by 1.6-4.2 times. Based on the indicators of aberrant cell frequency, spectrum of chromosome aberration types and the number of aberrations per an aberrant cell, it is the highest for radionuclide contamination of the reservoir-cooler of ChNPP, Semyhodskyi backwater, drainageway N 3 of ChNPP and Lake Hlyboke. The correlation between the level of chromosome aberrations and the scope of specific activity of radionuclides in water reservoirs was not observed, which can prove the induction of cytogenetic disorders in root meristem cells of wheat affected by low-rate radiation. Despite slight variation between spontaneous frequency of aberrant cells, induced by radionuclide contamination, the increased level of aneuploid cells and those with multiple chromosome aberrations confirms genetic danger for the organisms in the Prypiat River near Chornobyl city and Brahinka River. Taking into account high mutagenic efficiency of chronic low-rate radiation, the current radionuclide contamination of water reservoirs in the near alienation zone of ChNPP presents a serious genetic threat for the organisms.

\section{REFERENCES}

1. Glazko TT, Grodzinskiŭ DM, Glazko VI. [Chronic low doze ionizing irradiation and polyfactors of adaptation]. Radiats Biol Radioecol. 2006;46(4):488-93.

2. Morhun VV, Yakymchuk RA. Genetic consequences of the accident at Chornobyl NNP. Kyiv: Logos, 2010. $400 \mathrm{p}$.

3. Ma TH, Cabrera GL, Owens E. Genotoxic agents detected by plant bioassays. Rev Environ Health. 2005;20(1):1-13.

4. Shvets $L S$. Bioindication of the intensity of environmental pollution based on the fertility indicators of pollen grains of different plants. Achievements in biology and medicine. 2011; 17(1): 40-44.

5. Holosha VI. Radiological condition of the areas which belong to the zone of radioactive contamination (district breakdown). Kyiv: VETA, 2008. 49 p.

6. Gudkov DI, Kuz'menko MI, Kireev SI, Nazarov AB, Shevtsova NL, Dziubenko EV, Kaglian AE. [Radioecological problems of aquatic ecosystems of the Chernobyl exclusion zone]. Radiats Biol Radioecol. 2009;49(2):192-202.

7. Belova NV, Verigin BV, Yemelianova NG. Radiobiological analysis of white carp Hypophthalmichtys molitrix in a reservoir-cooler of Chernobyl NPP in a post-accident period. Issues of ichthyology. 1993; 33(6): 814-28.

8. Sazykina TG, Kryshev AI. EPIC database on the effects of chronic radiation in fish: Russian/FSU data. J Environ Radioact. 2003;68(1):65-87.

9. Artiukhov VG, Kalaev VN. [The cytogenetic monitoring of the environmental conditions on the territories exposed by the radioactive contamination as a result of Chernobyl Nuclear Power Station accident (colony Urazovo Belgorod region as an example)]. Radiats Biol Radioecol. 2006;46(2):208-15. 
10. Filenko $O F$. Biological methods in the quality control over the environment. Devices and control systems. 2007; 6: 18-20.

11. Dubinin NP, Kalchenko VA. Mutagenesis and radiation levels in the habitat of populations. News from AS of the USSR. Moscow: Nauka, 1980: 3-44.

12. Ofitserov MV, Igonina EV. [Genetic consequences of irradiation in a scots pine Pinus sylvestris L. population]. Genetika. 2009;45(2):209-14.

13. Ramzaev V, Bøtter-Jensen L, Thomsen KJ, Andersson $K G$, Murray AS. An assessment of cumulative external doses from Chernobyl fallout for a forested area in Russia using the optically stimulated luminescence from quartz inclusions in bricks. J Environ Radioact. 2008;99(7):1154-64.

14. DSTU ISO 5667-6-2001. Water quality. Sampling. Part 6. Instructions how to take samples in the rivers and other watercourses. Kyiv, 2002. 11 p.

15. DSTU ISO 5667-4-2003. Water quality. Sampling. Part 4. Instruction how to take samples in natural and artificial lakes. Kyiv, 2003. 11 p.

16. Pausheva ZP. Workshops in plant cytology. Moscow: Agropromizdat, 1988. $271 \mathrm{p}$.

17. Lakin GF. Biometrics. Moscow: Vysshaia shkola, 1990. 349 p.

18. Shevchenko VV, Grinikh LI. [Cytogenetic effects in native populations of Crepis tectorum exposed to chronic irradiation in the vicinity of the Chernobyl Nuclear Power Station. Induction of chromosome aberrations during the first 2 years following the accident]. Radiobiologiia. 1990;30(6):728-34.

19. Geras'kin SA, Fesenko SV, Aleksakhin RM. [The effects of non-human species irradiation after the Chernobyl nuclear accident]. Radiats Biol Radioecol. 2006;46(2):178-88.

20. Shmakova NL, Fadeeva TA, Nasonova EA, Krasavin EA, Rzianina $A V$. [Cytogenetic effects of low doses of radiation in mammalian cells: analysis of the hypersensitivity phenomenon and induced resistance]. Radiats Biol Radioecol. 2002; 42(3): 245-50.

21. Geraskin SA, Dikareva NS, Udalova AA, Vasiliev DV, Volkova PYu. After-effects of chronic radiation of pine long after the accident at Chernobyl NPP. Ecology. 2016; 1: 30-43.
22. Geras'kin SA, Mozolin EM, Dikarev VG, Udalova AA, Dikareva NS, Spiridonov SI, Teten'kin VL. [Cytogenetic effects in Koeleria gracilis Pers. populations from the Semipalatinsk proving ground]. Radiats Biol Radioecol. 2009;49(2):147-57.

23. Parshad R, Sanford KK. Radiation-induced chromatid breaks and deficient DNA repair in cancer predisposition. Crit Rev Oncol Hematol. 2001;37(2):87-96.

24. Liman R, Akyil D, Eren Y, Konuk M. Testing of the mutagenicity and genotoxicity of metolcarb by using both Ames/Salmonella and Allium test. Chemosphere. 2010;80(9):1056-61.

25. Geras'kin S, Oudalova A, Michalik B, Dikareva N, Dikarev $V$. Geno-toxicity assay of sediment and water samples from the Upper Silesia post-mining areas, Poland by means of Allium-test. Chemosphere. 2011;83(8):1133-46.

26. Medvedieva MYu, Bolsunovskiy AYa. Spectrum of chromosome aberrations in root meristem of E. canadensis from the areas of the Yenisei River with different types of technogenic pollution. Ecological genetics. 2016; 14(2): 57-65.

27. Sycheva LP, Zhurkov VS, Rakhmanin IuA. [Actual problems of genetic toxicology]. Genetika. 2013; 49(3):293-302.

28. Kovaleva VI, Bagatskaia NV. [Cytogenetic effects in peripheral blood lymphocytes in the offspring of Chernobyl nuclear power plant accident liquidators under the influence of mitomycin $\mathrm{C}$ in vitro and folic acid in vivo]. Tsitol Genet. 2013;47(1):68-73.

29. Kutsokon' NK, Bezrukov VF, Lazarenko LM, Rashydov NM, Hrodzyns 'kyı DM. [The number of aberrations in aberrant cells as a parameter of chromosomal instability. 1. Characterization of dose dependency]. Tsitol Genet. 2003;37(4):20-5.

Цитогенетичні порушення в клітинах Triticum aestivum $L$. за дії радіонуклідних забруднень водойм зони відчуження Чорнобильської АЕС

\section{Р. А. Якимчук}

Мета. Вивчити частоту та спектр хромосомних аберацій в клітинах кореневої меристеми Triticum aestivum L. за пролонгованої дії радіонуклідного забруднення водойм ближньої зони відчуження Чорнобильської АЕС. Методи. Вплив водними розчинами мутагенів на на- 
сіння й проростки рослин. Ана-телофазний метод аналізу хромосомних аберацій на давлених цитологічних препаратах апікальної меристеми первинних корінців. Результати. Радіонуклідне забруднення водойм ближньої зони відчуження ЧАЕС викликає зростання в 1,6-4,2 рази частоту аберантних клітин та порушень мітозу. Найвищий рівень цитогенетичної активності характерний для радіонуклідного забруднення водоймиохолоджувача ЧАЕС, Семиходського затону, відвідного каналу № 3 ЧАЕС та озера Глибоке. Спектр типів представлений переважно одиничними та парними ацентричними фрагментами, мостами й відстаючими хромосомами. Висновки. Пролонгована дія іонізуючого випромінювання радіонуклідних забруднень водойм ближньої зони відчуження ЧАЕС характеризується високою цитогенетичною активністю. Залежності між рівнем хромосомних аберацій та величиною питомої активності радіонуклідів водойм не виявлено, що може свідчити про індукування цитогенетичних порушень опроміненням в діапазоні низьких доз. Підвищений рівень анеуплоїдних клітин та клітин 3 множинними хромосомними абераціями свідчить про генетичну небезпеку для організмів водойм навіть 3 низькою питомою активністю радіонуклідного забруднення.

Кл юч о в і с л о в а: аберації, цитогенетичні порушення, радіонукліди, низькодозове опромінення.

\section{Цитогенетические нарушения в клетках Triticumaestivum $L$. при действии радионуклидных загрязнений водоемов зоны отчуждения Чернобыльской АЭС}

\section{Р. А. Якимчук}

Цель. Изучить частоту и спектр хромосомных аберраций в клетках корневой меристемы Triticum aestivum L. при пролонгированном действии радионуклидного загрязнения водоемов ближней зоны отчуждения Чернобыльской АЭС. Методы. Влияние водными растворами мутагенов на семена и проростки растений. Ана-телофазный метод анализа хромосомных аберраций на давленных цитологических препаратах апикальной меристемы первичных корешков. Результаты. Радионуклидное загрязнение водоемов ближней зоны отчуждения ЧАЭС вызывает возрастание в 1,6-4,2 раза частоту аберрантных клеток и нарушений митоза. Самый высокий уровень цитогенетической активности характерный для радионуклидного загрязнения водоема-охладителя ЧАЭС, Семиходской заводи, отводящего канала № 3 ЧАЭС и озера Глубокое. Спектр типов преимущественно представлен единичными и парными ацентрическими фрагментами, мостами и отстающими хромосомами. Выводы. Пролонгированное действие ионизирующих излучений радионуклидных загрязнений водоемов ближней зоны отчуждения ЧАЭС характеризуется высокой цитогенетической активностью. Зависимости между уровнем хромосомных аберраций и значением удельной активности радионуклидов водоемов не выявлено, что может свидетельствовать о индуцировании цитогенетических нарушений облучением в диапазоне низких доз. Повышенный уровень анеуплоидных клеток и клеток с множественными хромосомными аберрациями свидетельствует о генетической опасности для организмов водоемов даже с низкой удельной активностью радионуклидного загрязнения.

К л юч е в ы е с л о в а: аберрации, цитогенетические нарушения, радионуклиды, низкодозовое облучение.

Received 03.09.2017 